\title{
Class Formation and the Labor Movement as the Subject of Dialectic Social History
}

\author{
HARTMUT ZWAHR
}

\section{Introduction}

As an introduction to this essay, three points need to be made. First, the European labor movements of the nineteenth and early twentieth centuries, on which we focus here, were part of bourgeois society. Secondly, they were a factor that challenged bourgeois society and thus contributed in several different ways to its change. Thirdly, as a result of this interaction, the labor movements themselves underwent changes. All of those were lasting changes. The systemic changes, imposed by revolutionary or military force, that accompanied the experiment in socialism, were not. In countries where the labor movement pursued socialist aims prior to the First World War on the crumbling foundations of a primarily prebourgeois society, such as in eastern and south-eastern Europe, it was the most radical force behind political democratization and modernization (Russia; Russian Poland: the Kingdom of Poland, ${ }^{1}$ Bulgaria). But it could not compensate for the society's evident lack of basic civic development, whereas the socialist experiment in Soviet Russia led not only to the demise of democratization but also to a halt of embourgeoisement. ${ }^{2}$

The collapse of institutionalized (party-administrated) socialism, that is, the (state) communist branch of the labor movement in Europe, has prompted the large community of labor historians to ask how the achievements, effects, and experiences of the nineteenth-century labor movements should be evaluated both in light of these new experiences and with respect to the recent crises in civilization. What did millions of wage earners contribute to bourgeois society simply by living and working in this society, by endeavoring to give their lives direction, honor and meaning, by creating movements and placing their hopes in these? More specifically, how have labor movements contributed to the realization of demands for civil liberty and emancipation while caught in the tension between economic and social inequality, on the one hand, and the universal character of such demands, on the other? In particular, what role did the social democratic-socialist movements play in calling for social and political

\footnotetext{
' See Ryszard Kolodziejczyk (ed.), Historia Polskiego Ruchu Robotniczego do 1890 (Warsaw 1890); Stanislaw Kalabinski (ed.), Polaska klasa robotnicza. Zarys dziejow, Vol. 1/2: Lata 1870-1918 (Warsaw 1978).

${ }^{2}$ See Alan Bullock, Hiller und Stalin. Parallele Leben (Berlin 1991); Wolfgang Ruge, "Die Doppeldroge. Zu den Wurzeln des Stalinismus", in Rainer Eckert, Wolfgang Kuttler, Gustav Seeber (eds.), Krise - Umbruch - Neubeginn. Eine kritische und selbstkritische Dokumentation der DDR-Geschichtswissenschaft 1889/90 (Stuttgart 1992), pp. 33-43.
} 
equality and in laying the groundwork for the initial attempt at socialism that began to take shape during the First World War; and what role did the trade union movements play in trying to formalize the relations between capital and labor in the interests of the worker? The demise of the model of socialism based on a communist type of planned economy currently appears to have restored an older sense of European normality and revived earlier trends of European history. Yet it had been from these trends and in confrontation with the realities of capitalism that the vision and the alternative of a non-bourgeois society in the foreseeable future evolved. It was Marx's doctrine that first gave the labor movement a certain goal based on universal ideas, a "global mission". ${ }^{3}$ Otherwise it could have remained a simple trade union movement. However, the unity required for this "mission" was constantly lacking. Thus, the history of the labor movement has always been one that suffered denominational, national and political division.

I would like to close these remarks by listing several major topics. These are fields of research of a dialectic social history that thinks and proceeds in a functional context and that does not isolate the history of workers and labor movements, but seeks to view these within the framework of a history of the entire society (Gesellschaftsgeschichte).

(1) class formation, especially that of the bourgeoisie in relation to the working class and vice versa; (2) class and gender: work, division of labor, etc.; (3) the relationship between wage labor and capital, social inequality and participation; (4) cultural processes of embourgeoisement and the limits of their impact among workers; (5) grassroots movements, labor and other movements; (6) state, classes and movements; (7) legal regulation of wage labor and class formation; (8) the achievements of organizations and institutionalization: trade unions and entrepreneurial associations, the trade unions as the prototype of modern interest representation of the dependent employee, social democracy as a modern mass party; (9) the public counter-sphere (Gegenöffentlichkeit), alternative societal concepts, utopias.

\section{Synchronization and transformation of labor}

The present study of class formation is based on the idea of synchronization. Synchronization means to discover the simultaneity between two

${ }^{3}$ Emst Nolte, Nietzsche und der Nietzscheanismus (Frankfurt a.M. and Berlin 1990), p. 8.

- See Hartmut Zwahr: "Zur Synchronisierung des Entwicklungsgangs von Bourgeoisie und Proletariat als Forschungsproblem und Aufgabe", Beitröge zur Geschichte der Arbeiterbewegung 23 (1981), pp. 803-824; Jurgen Kocka (ed.), Arbeiter und Barger im 19. Jahrhundert. Varianten ihres Verhaltnisses im europäischen Vergleich (Munich 1986). On the terminology (Burgerlichkeit, Entburgerlichung), see Jurgen Kocka, "Burgertum und Burgerlichkeit als Probleme der deutschen Geschichte vom spăten 18. zum 19. Jahrhundert", in Jügen Kocka 
agents, that is, to proceed in a manner that synchronously, simultaneously and concurrently explores the actual give and take between these interacting agents instead of isolating them from one another. With regard to class formation among wage laborers and entrepreneurs, including other bourgeois groups, this means studying a pair of opposites as a unit and as interacting agents. This also means describing the capital relation as a fundamental economic given, as well as a power system, which is undergoing constant transformation - socially, mentally, intellectually, culturally and politically. This is because wage labor in capitalism arises primarily as a function of capital. ${ }^{5}$ It is included in the historical development of private property, usually originating in a feudal framework. Not until the defeudalization of labor did the classes of bourgeois society evolve. The participants could not flee from this fundamental setting as long as they operated within it. Therefore, they were also not free in their decisionmaking but bound to one another. However, it is still not commonplace in the economic and social history of either workers or entrepreneurs thoroughly to study the synthesis and interaction of these antipodes.

In modern history, the major transformation of labor to free labor, 6 brought about by revolution, reform, or both in the transition to capitalism, ${ }^{7}$ did not alter the fact that working methods were still based on manual labor. It overcame the partially feudal, partially corporate, partially privitege-based, non-economic restraints, freed the capital relation and created both inside and outside of this relation the principal prerequisites needed for a transformation to modern industrial labor. Industrial capitalism, however, evolved without the intervention of political force. This was limited for the most part to a temporary protective function as industries were established and credit granted. During the transition from manual labor to mechanization, the umbilical cord that linked the machine laborers of the capitalist era to the wage laborers of earlier centuries of European history was cut. But it was not only the unpropertied who left the pre-class state and entered into the reality of class formation in industrial capitalism. ${ }^{8}$ All around them and before their eyes, large groups of both burgher and proto-industrial rural dwellers were being wrenched out of

(ed.), Burger und Burgerlichkeit im 19. Jahrhundern (G8ttingen 1987). Also see the editor's introduction.

'See Hartmut Zwahr, "Zum Gestaltwandel von gewerblichen Unternehmem und kapitalabhăngigen Produzenten. Entwicklungstypen gewerblicher Warenproduktion in Deutschland", Jahrbuch far Geschichte 32 (1985), pp. 9-64.

- Karl Marx, Das Kapital, Vol. 1, in Marx/Engeis Werke, Vol. 23 (Berlin 1988); Max Weber, Wirtschaft und Gesellschaft. Studienausgabe (Tubingen 1980), pp. $70 \mathrm{ff}$. (on free and unfree labor).

'Hartmut Zwahr, "Die Konstituienung der Arbeiterklasse in revolutionsgeschichtlicher Sicht", in: Proletariat und bilrgerliche Revolution (1830-1917) (Berlin 1990), pp. 33-55.

- See Jurgen Kocka, Weder Stand noch Klasse. Unterschichten um 1800 (Bonn 1990); Jurgen Kocka, Arbeitsverhallnisse und Arbeiterexistenzen. Grundlagen der Klassenbildung im 19. Jahrhundert (Bonn 1990). 
corporate constraints, artisan independence, as well as earlier forms of capital dependency by the political transformation and the demise of feudalism. This was proletarianization, the fate of large numbers of people whose station in preceding centuries had been far above those of urban day laborers, the packers, artisans, masons, carpenters, and those dependent on wages in general. Next came the integration into the still developing system of profit-seeking and free labor characteristic of industrial capitalism. The labor power of these people was essential for capitalist industrialization, not only since industrialization developed at a different pace in the various important branches of industry, but also because it evolved in close relationship with artisan and pre-industrial forms of production. Women and girls also joined the labor force to an unprecedented degree. Mechanized spinning mills became the pilot industry of the Industrial Revolution on the European continent. In Germany the first regions affected were Saxony ${ }^{9}$ and the Rhineland. ${ }^{10}$ Therefore it was the specific manner in which class formation occurred within light industry (see below) that marked the beginning of the history of German workers and the working class. An example of this would be the strike of roughly 2,000 cloth mill workers in and around Lennep (Bergisches Land) for higher wages, shorter working hours, negotiated contracts, and the right to elect foremen. ${ }^{11}$

The competition from the factories had forced most of the cloth weavers of the region to give up their trade. In the factories they experienced how the traditional artisan labor lost its commodity value and how the commercialization of labor depended on the transition to industrial labor, which went hand-in-hand with unusual, painful forms of control. The workers complained that the machine is "not the tool of workers, but the worker [is] the tool of the machine, the slave of awe-inspiring mechanics" (expressed in the words of an artisan). In conjunction with such dequalification, the clothmakers also experienced an estrangement from the purpose of human labor and of life as a whole. "The machine makes any skill superfluous and only requires a dull mechanic supervision." - "We are not allowed to be hungry until the bell rings [ . . ] Should hunger strike too soon, that is considered disruptive and is not tolerated." The industrial order replaced the natural order; with the destruction of the household unit of production, a familiar cohesion of life was destroyed. The conflict

- See Rudolf Forberger, Die Industrielle Revolution in Sachsen 1800-1861, Vol. 1/1: Die Revolution der Produktivkräfte in Sachsen 1800-1830 (Berlin 1982); Vol. 12: Ubersichten zur Fabrikentwicklung compiled by Ursula Forberger (Berlin 1982).

${ }^{10}$ See Gerhard Adelmann (ed.), Der gewerblich-industrielle Zustand der Rheinprovinz in Jahre 1836 (Bonn 1967).

"See Dieter Dowe, "Der Arbeitskampf in den Tuchfabriken des Kreises Lennep (Bergisches Land) 1850", in Klaus Tenfelde and Heinrich Volkmann (eds.), Streik. Zur Geschichte des Arbeitskampfes in Deutschland während der Industrialisierung (Munich 1981), pp. 31-51. 
between capital and labor shifted from the relations between workers in home industries and the merchants and Verleger to the factory. Once residential dwelling and workplace had been separated, the factory became the 'place where the conflict between capital and labor erupted. Strikes and lock-outs brought the confict to a dangerous, pre-revolutionary head. Entrepreneurs and wage laborers now treated both victory and defeat as part of a bilateral process of learning. This is sufficient reason to avoid any separation of such phenomena in social history and to present relations within capitalism in a synchronized and comparative fashion.

\section{Types of class formation in the capital relation}

When comparing the genesis of entrepreneurs and wage laborers, a distinction can usually be made between a type of class formation particular to light industry and one characteristic of heavy industry. ${ }^{12}$ Within these two types of industry and their affiliated branches, to a certain extent entrepreneurs and wage laborers born to the working class are to be found. They represented a variation of class formation that began as a partnership and led to social inequality. During this change, patriarchial forms of social intercourse were discarded, although some aspects persisted. ${ }^{13}$

The antipodes of the capital relation in light industry, especially in the textile trade

At the heart of the manner in which class formation developed in light industry lay the earlier dependencies of the producer in proto-industrial contexts. Several aspects about the interdependent social groups reveal an identical or at least very similar degree of economic, social and political maturity. Abilities, value consciousness, etc. had sprouted from the same root, the same strand of development. An imagery that could be used to characterize the participants in any particular moment of conflict or conflict-avoidance would be that of a pair of wrestlers of equal weight and experience.

When the origins of non-agrarian entrepreneurs and wage laborers are studied, it is clear (as Germany illustrates) that employers born to the entrepreneurial class dominated. With the exception of mechanical engineering and those branches of production that grew primarily out of artisan crafts, one might assume that such a dominance existed in both light and heavy industry. On the entrepreneurial side there were indeed family and business links between both types of industry. With regard to wage laborers, however, what stands out are only the obvious differences. It is not

"See Zwahr, "Gestaltwandel", pp. 52-59.

13 See Jurgen Kocka, "Traditionsbindung und Klassenbildung. Zum sozialhistorischen Ort der fruhen deutschen Arbeiterbewegung", Historische Zeitschirft 243 (1986), pp. 333-376. 
possible to find a similar hereditary element among wage laborers in the initial stages of class formation. Wherever capitalism evolved from the triad of manufacturing, capital-dependent craft and factory, the two interacting social groups possessed a similar social and mental maturity. This did not exist in the emerging centers of heavy industry during this period.

Pre-industrial entrepreneurs preferred to live in cities and large industrial villages; their financial institutions were located in the cities, which were at the same time the leading commercial centers of industrial regions. The cities had profited from the surplus of the proto-industries that flourished and expanded throughout the eighteenth century. The capital needed to make the first industrial investments accrued in the cities. In turn, most of these investments were made in traditional regions of export trade. These included the Silesian Eulengebirge (linen weaving; in 1844 the site of the Silesian weavers revolt), the later industrial region of the Vorerzgebirge (cotton weaving, mechanical spinning mills, mechanical engineering), ${ }^{14}$ the Saxon Vogtland (weaving, lace manufacturing), the Schönburgische Rezeßherrschaften of Saxony (cotton weaving), ${ }^{15}$ the south-east of Oberlausitz (linen weaving), ${ }^{16}$ the Bergische Land: Barmen and Elberfeld (cotton weaving), the metal-producing region of Solingen, ${ }^{17}$ Krefeld (silk weaving). ${ }^{18}$ At the turn of the eighteenth to the nineteenth century, these regions were dominated by entrepreneurs born into the class. For the most part, they came from families of merchants and Verleger, some of which, in turn, had come themselves from families of small manufacturers. Examples of the type of class formation to be found in light industry outside of Germany include the silk weaving region around Lyon, ${ }^{19}$ the English textile regions, the textile region of Lodz in Russian

14 See Rudolph Strauss, Die Lage und die Bewegung der Chemnitzer Arbeiter in der ersten Hailfte des 19. Jahrhunderts (Berlin 1960); on Saxony, see Hartmut Zwahr, "Die deutsche Arbeiterbewegung im Länder und Territorienvergleich 1875", Geschichte und Gesellschaft 13 (1987) 4, pp. 464-471; Gerhard A. Ritter, "Das Wahlrecht und die Wahlerschaft der Sozialdemokratie im Konigreich Sachsen 1867-1914", in Gerhard A. Ritter (ed.), Der Aufstieg der deutschen Arbeiterbewegung. Sozialdemokratie und Freie Gewerkschaften im Parteiensystem und Sozialmilieu des Kaiserreichs (Munich 1990), pp. 49-101.

is See Hans-Albrecht Grohmann, "Kapital und Lohnarbeit in den Schönburgischen RezeBherrschaften. Zur Konstituierung von Bourgeoisie und Arbeiterklasse in einer deutschen Exportgewerbelandschaft 1830-1852", Ph.D. thesis (Leipzig 1988).

${ }^{16}$ Heinz-Dieter Fleißig, "Untersuchungen zur Klassenkonstituierung der Bourgeoisie in der suldlichen Oberlausitz zur Zeit der industriellen Revolution unter besonderer BerUcksichtigung der ökonomischen Konstituierung und deren Grundlagen im Textilgewerbe", Ph.D. Thesis (Dresden 1988).

"See Rudolf Boch, Handwerker-Sozialisten gegen Fabrikgesellschaft. Lokale Facivereine, Massengewerkschaft und industrielle Rationalisierung in Solingen 1870-1914 (Gottingen 1985).

"See Peter Kriedte, "Eine Stadt am seidenen Faden". Haushalt, Hausindustrie und soziale Bewegung in Krefeld in der Mitte des 19. Jahrhunders (Gorttingen 1991).

19 See Yves Lequin, Les ouvriers de la région Lyonnaise (1848-1914), Vol. 1: La formation de la classe ouvrière régionale, Vol. 2: Les interests de classe et la république (Lyon 1977). 
Poland, ${ }^{20}$ and the Russian textile regions (such as the Ivanovo-Kineshma region). ${ }^{21}$ With regards to the development of the artisan crafts, protoindustry, decentralized and centralized manufacturing, and finally the factory, the urban-rural comparison of class formation ${ }^{2}$ clearly indicates a certain balance in the developmental pattern of entrepreneurs and wage laborers.

In a certain historical-political milieu, all those conflicts surfaced that were to accompany the industrial-capitalist type of production. Sooner or later, the factory and the factory system became predominant. They began to destroy pre-industrial, long established methods of production and ways of living. The guilds were alarmed as the new force of the industrial bourgeoisie penetrated their existence from without, so to speak, and left artisan labor at the mercy of competition. They fought against a form of production that, in their opinion, "still dangled in a very uncertain legal state ${ }^{122}$ from which the market relationships of the industrial bourgeoisie developed. As the united Leipzig guild masters warned in a petition to the Landtag, England's manufacturing and factory system also started

in very small spots where there were no guilds, in Manchester, Birmingham and Liverpool, and with time, these boroughs came to be counted among Fingland's most important cities. Manufacturing in our fatherland has developed in a similar manner. It also started in small cities and areas where no important guilds existed, and in turn these communities grew and expanded and were profitable to their inhabitants. ${ }^{24}$

For the first time, many journeymen in the guilded crafts discovered that being wage-dependent was no longer merely a short step toward petty bourgeois independence, but a permanent way of life. The overcrowding of the crafts became a mass phenomenon. Master craftsmen were deciding in ever-growing numbers not to have their sons learn the trade of their fathers. Many quit when they could no longer lower the prices of their

${ }^{20}$ See G. Missalowa, Studia nad powstaniem lodzkiego okregu przemyslowego 1815-1870, Vol. 1: Przemysl (Lodz 1964); Vol. 2: Klasa robotnicza (Lodz 1967); Vol. 3: Burzuazja (Lodz 1975).

${ }^{21}$ Daniel Mandes, "The Ivanovo-Kineshma Region Working Class. A Case Study of the Russian Labour Movement in the Province, 1914-1917", paper presented at a colloquium on comparative labor history, Cortona, June 1986.

${ }^{2}$ On this topic, see Hartmut Zwahr, "Zur Genesis der deutschen Arbeiterklasse. Stadiale und regionale Entwicklungsformen des deutschen Proletariats im Vergleich", in: Zur Entstehung des Proletariats (Magdeburg 1980), pp. 25-49; idem, "Arbeiterbewegung im Landerund Territorienvergleich", pp. 448-507; idem, "Der Ubergang der Arbeiterbewegung in die Provinz. Einsichten am Beispiel Deutschlands, 1848-1900", in: Rudolf G. Ardelt and Erika Thurner (eds.), Bewegte Provinz: Arbeiterbewegung in mitteleuropdischen Regionen vor dem Ersten Weltkrieg (Vienna and Zurich 1992), pp. 63-86.

${ }^{23}$ See Petition, uberreicht der Königlich-Sächsischen Ständeversammlung von den endesunterscluriebenen Innungen und Personen der Seadt Leipzig in Jahre 1839, p. 14.

${ }^{24}$ Ibid., pp. $83 f$. 
goods to match those of cheaply manufactured goods. Others, such as the linen weavers, clothmakers, and knitters, had to resort to sweating.

The "bourgeoiseness" (Burgerlichkeit) in light industry could not do without free labor, competition and a national market. Its success led to the proletarianization of large segments of the pre-industrial classes and changed workers' images of themselves. "Anti-bourgeoiseness" (Antibilrgerlichkeit) became part of increasingly radical protests. People of petty bourgeois origin, unlike those of agrarian origin, began to consider civil values and ideals for the first time in a perspective that was to transcend bourgeois society. ${ }^{25}$

Particularly in the villages and cities of the older regions of exportoriented industries, working conditions under pre-industrial and, later, industrial capitalism and its various mixed forms produced a type of worker unknown to agrarian regions. Nor did he or she exist in the central regions of heavy industry at the time. This type of person introduced into the labor movement abilities and experiences, an already strong urban culture and way of life, self-confidence, a desire to live humanely and, in the opinion of a minority, to govern society. He or she helped create this first major mass movement of modern times. Wilhelm Liebknecht described one such worker-socialist who stemmed from the long evolution of capital-dependent, producing families, namely Christian Hadlich. Born in 1831 as the son of a stocking knitter master in Hirschberg (Silesia), Hadlich had become a journeyman in his father's trade.

In Christian Hadlich I met a type of person for the first time in Germany that I would later meet often in the Saxon Erzgebirge and Vogtland: from the brown, lively eyes radiated intelligence and great kindness, the body weak - the result of degeneration caused by several generations of hunger and deprivation - the countenance the expression of painful comprehension, deep reflection and a probing awareness of human misery, which he himself had experienced and felt in the suffering of others [ . . ]. I do not know what year he came to Leipzig. From casual remarks one can deduce that he was there in 1848 and 1849 at least temporarily, and that he then belonged, or at least frequented the former workers' association, which had a strong "communist bias". When I arrived in Leipzig, he was already one of the most active board members of the workers' education association [ . . . ]. He was the soul of the association, to which he devoted all thought and deed. We quickly became friends. And he was the first of my new associates to declare himself wholeheartedly for socialism. ${ }^{26}$

Other workers in Leipzig and comparable cities, among them a good many sons of peasants, fought with grim determination to become civil servants for the railroad or the postal service. ${ }^{27}$ Petty bourgeois enterprises, such

${ }^{25}$ See Hartmut Zwahr, "Verbürgerlichung und Entbürgerlichung beim Übergang zum Industriekapitalismus. Ein süchsisch-polnischer Vergleich", Neues Archiv filr sächsische Geschichte, forthcoming.

${ }^{26}$ Wilhelm Liebknecht, Erinnenungen eines Soldaten der Revolution (Berlin 1976), pp. 323f.

$n$ See Susanne Schötz, "Zur Entstehung und Beamtung von Postpersonal. Das Beispiel Leipzig", Jahrbuch fur Regionalgeschichte 12 (1985), pp. 172-188; idem, "Städtische Mittel- 
as that of small-scale, fresh produce retailer or pub owner, also offered chances to enter into an occupation with opportunities to improve one's lot. ${ }^{28}$ Sons of peasants and agricultural laborers were very rarely among the first and second generations of the pioneers of the social democratic labor movement. Whereas the sons of artisans who became wage laborers usually experienced proletarianization as a social decline, the sons of peasants who went to the cities and became wage laborers appear to have found more avenues for social advancement than has been generally thought. They also endured dependencies that those from the lower urban social strata either completely refused to accept or only reluctantly put up with. Biographical evidence clearly shows these differing approaches to life. ${ }^{29}$ For the most part, it was the fate of the artisan to experience "debourgeoisement" (Entbiirgerlichung). Where this was transformed into the anti-bourgeois sentiments that were to become so vital to the early social democratic-socialist labor movement, these same people also possessed education, ideals, a longing for utopia, and a political culture rooted in bourgeois origins. From this they acquired an important set of emancipating ideas and behavior, which must also be seen primarily as a bourgeois inheritance. ${ }^{30}$ The republicanism espoused by large segments of the working class, such as Bebel found in the 1860s in the kingdom of Saxony, ${ }^{31}$ is rooted in the 1848 revolution. To a degree, this remaining spark of permanent politicization fueled the fires of socialist republicanism. How easily the worker-socialists moved in the red-tinged imagery of the socialist vision! Both the profession of faith and the commitment it earned from the masses are to be considered as achievements of the social democratic movement which would create a new culture based on earlier traditions. ${ }^{32}$

We also come across the capital-dependent, artisan type of producer in the small-scale metal industry of the Bergische Land and the Prussian Mark. There he or she established a specific type of labor movement that

schichten in Leipzig während der bürgerlichen Umwalzung (1830-1870), untersucht auf der Grundlage biographischer Massenquellen", Ph.D. thesis (Leipzig 1985).

28 Ibid.

29 Susanne Schötz, "Karriereverhalten in Umbruchzeiten: Zur Rekrutierung von Leipziger Kleinburgergruppen während der industriellen Revolution (1830-1870)", in Georg G. Iggers (ed.), Ein anderer historischer Blick. Beispiele ostdeutscher Sozialgeschichte (Frankfurt a.M. 1991), pp. 56-69; idem, "Zur Konstituierung 'kleiner' Selbständiger wăhrend der bürgerlichen Umwallzung in Leipzig. Ein Beitrag zur messestadtischen Sozialgeschichte", Jahrbuch filr Geschicite 38 (1989), pp. 39-94.

${ }^{30}$ See Hartmut Zwahr, "Konstitution der Bourgeoisie im Verhältnis zur Arbeiterklasse. Ein deutsch-polnischer Vergleich", in Jurgen Kocka (ed.). Bürgertum im 19. Jahrhundert. Deutschland im europätischent Vergleich, Vol. 2 (Munich 1988), pp. $178 \mathrm{ff}$.

"See August Bebel, "Aus dem Anfang der Arbeiterbewegung", in: Die Grindung der Deutschen Sozialdemokratie (Leipzig 1903), p. 8.

${ }^{32}$ See Hartmut Zwahr, "Namen, Symbole und Identitáten Gealchteter im 19. Jahrhundert", in Manfred Lechner and Peter Wilding (eds.), "Andere" Biographien und ihre Quellen. Biographische Zugänge zur Geschichte der Arbeiterbewegung. Ein Tagungsbericht (Vienna and Zurich 1992), pp. 27-35. 
was supported through the organization of craft associations. ${ }^{33}$ In addition to these, the German Metal Workers' Association became the most important industrial trade union beginning in 1891. The breakthrough to a mass union was due to the flood of skilled wage laborers. It occurred despite the resistance put up by the united front of the "old working class" in the craft unions. In this conflict, capital-dependent piece workers clashed with machine-dependent factory workers. The older "artisan socialists" criticized the direction that technological development in capitalism was taking. They believed that eventually a working class would emerge that would lose the ability "to one day confront the masters in the factory and in society and to organize production on their own". ${ }^{34}$

The logic of capitalism, as it emerged in a fully developed form in textile production from within the triad of manufacturing, crafts dependent on capital, and the factory system, was actually one of the strongest forces behind the embourgeoisement during the transition to industrial capitalism. In her statistical studies on Germany in the period after customs unification, the economist Gertrud Hermes claims that this was to be of great importance for the country. "The textile trades were the strongest industrial power to oppose the large landowners." ${ }^{35}$ She notes that this industrial sector also supplied Ferdinand Lassalle and Friedrich Engels the financial means "to complete their life work". The textile industry was the first industry to press for civic ideals and practices in Germany and elsewhere. It also pioneered various new frontiers of bourgeois pursuit. Contrary to the sector of mining and smelting industry, which often evolved from large landowning, this industry did not have roots in an earlier feudal past. There is no evidence that the state bureaucracy exercised any supervision over the textile industry comparable to that of mining or, in fact, its control over the German railways. Once freed from the shackles of a system of state control and special privileges, industrial textile production was subjected to strong pressure from international competition. As a result of this, adaptation to everything that constituted an international industrial "bourgeoiseness" was especially urgent. Manufacturers demanded rights of representation and constitutional rights, trade and manufacturing legislation, credit institutions for industry, protection for inventions and patterns, trade schools and training programs, a revamping of the transportation system, an infrastructure beneficial to industry, and much more. The logic of capitalism and its impact on industrial production and reproduction finally deprived the artisan-bourgeoisie, the Handwerker-Bürger, of its longing for a life in a free, classless society of citizens. However, in the view of the leading members of the economic

"See Boch, Handwerker-Sozialisten, pp. 79ff.

34 lbid.

"3s Gertrud Hermes, "Statistische Studien zur wirtschaftlichen und gesellschaftlichen Struktur des zollvereinten Deutschland", Archiv fur Sozialwissenschaft und Sozialpolitik 63 (1930), p. 136. 
bourgeoisie, the Wirtschafisburger, this was an unavoidable step down the "English road". .6

The antipodes of the capital relation in heavy industry

With regards to the sector of heavy industry, we discover a type of class formation in which the interacting social elements are very unequal, indeed extremely unequal. When the location of iron and coal deposits dictated it, industrial plants and factories sprung up in the middle of nowhere, so to speak. The central regions of heavy industry in the German economy gradually evolved like this in Silesia, the Rhine and Ruhr valleys, and the Saar. The majority of the investors had been born into entrepreneurial families. The biographies also trace their lineages to the entrepreneurial dynasties of earlier kinds of urban trade centers, although individual cases cannot be discussed here. Contrary to the entrepreneurs, most of the workers in the coal mines and smelting foundries came from villages. They came from peasant families and from families who belonged to the - poorest in the villages. All of these people, including the tens of thousands of Poles in the Ruhr region, ${ }^{37}$ arrived in the developing industrial regions and mining colonies with a great willingness to adapt. As a rule, they respected state authorities much longer and attempted to maintain a way of life customary to village life. Catholic pastoral care knew how to integrate these miners and foundry workers into a new environment of heavy industry. Originally, this type of worker contributed little to the social democratic labor movement. ${ }^{38}$ The experience of the First World War wrenched a greater part of the younger generation out of the traditional societal order. Hence, entrepreneurs and wage laborers squared off like a poorly matched pair of wrestlers, to continue the metaphor. The parity between textile entrepreneurs and the workforce in the industrial regions of Russian Poland was also very unequal ever since the formerly subservient peasants and their sons from the large estates had lost their employment through agricultural reform, and vast numbers of them had become unskilled or semi-skilled factory workers. ${ }^{39}$

36 Sce Rudolf Boch, "Von der 'begrenzten' zur forcierten Industrialisierung. Zum Wandel bkonomischer Zielvorstellungen im rheinischen Wirtschaftsbürgertum 1815-1845", in HansJurgen Puhle (ed.) Burger in der Gesellschaft der Neuzeit. Wirtschaft - Politik - Kultur (Gottingen 1991), p. 149.

${ }^{37}$ On this topic, see Christoph Kleßmann, Polnische Bergarbeiter im Ruhrgebiet 1870-1945. Soziale Integration und nationale Subkulhur einer Minderheit in der deuzschen Industriegesellschaft (Gottingen 1978).

3* See Klaus Tenfelde, Sozialgeschichte der Bergarbeiterschaft an der Ruhr im 19. Jahrhundert (Bonn 1981); Klaus Tenfelde and Helmuth Trischler (eds.), Bis vor die Stufen des Throns. Bittschriften und Beschwerden von Bergleuten im Zeitalter der Industrialisientung (Munich 1986); for a more comprehensive study, see Gerhard A. Ritter and Klaus Tenfelde, Arbeiter im Deutschen Kaiserreich 1871-1914 (Bonn 1992), pp. 298ff., 390ff.

${ }^{39}$ See Zwahr, "Konstitution der Bourgeoisie", pp. 158f., $173 f$. 
At this point it needs to be demonstrated, briefly, that entrepreneurs and wage laborers of working-class origin sprung from the same social turf. The actors of future capitalism resembled one another like two peas in a pod. Social inequality stemmed from a state of sameness. The original social balance can be best demonstrated (and biographically best illustrated) in the field of mechanical engineering. The founders (inventors, builders, industrial pioneers) usually had a background in the crafts. They sought occupational training as wage laborer-journeymen in the developing industrial plants (manufacturing factory at the time still meant building machines and appliances each individually, no production line assembly). They became foremen, masters, and factory managers before they dared to become self-employed. They took this step with little capital of their own, but with a great deal of ability and a strong will to work hard. As masters of their craft, they became experts and drew to their side friends, acquaintances and colleagues from the ranks of skilled workers both in the factories and the artisan shops. In the original plant, a type of production democracy temporarily prevailed. This fell apart as the dynamics of capitalism began to polarize and to dominate those involved in production. The production democracy of social equals, to remain with a concept that is perhaps a bit too "strong", was replaced step-by-step by personal power. Work regulations were introduced that clearly assigned duties and stipulated restrictions within a framework of hierarchical, authoritative management and subordination. It heralded the beginning of class divisions among the groups involved in production.

The most prominent of all known examples of this is Chemnitz. In the mid-1860s, numerous machinists refused to acknowledge factory regulations that had been drafted by the largest entrepreneurs in accordance with Saxon trade law. They also refused to submit to the master-of-thehouse stance taken by former comrades, the social climbers of newly acquired wealth. They left their jobs and founded the German Machinists' Company (Deutsche Maschinenbau-Arbeiter-Kompanie), organizing it as a volunteer association. ${ }^{40}$ More than one hundred production workers attempted to replace bourgeois management with the cooperative selfadministration of wage labor. Although this experiment in selfdetermination failed, it deserves attention. It reveals an elementary need for work relations devoid of power struggles and based on cooperation, but it also illustrates the fundamental difficulties that arose for a plant managed on a cooperative basis in a market economy. The original partnership was replaced by relationships dominated by power. This was paralleled by a concentration of capital and the transformation of the earlier artisan-entrepreneur into a "factory boss" as a result of market conditions.

40 See Ernst Hofmann, "Die Deutsche Maschinenbau-Arbeiter-Kompanie in Chemnitz (1863-1867)", Jahrbuch far Wirsschaftsgeschichte 1983-III, pp. 77-105. 
Bases of class formation

The social basis of class formation ${ }^{41}$

The social basis of class formation was a given already during the phase when an enterprise was being established, that is during the economic formation of a particular form of capitalism. Clearly discernable patterns of recruitment, characteristic marriage circles, milieus, etc., were typical of the social profile for both wage laborers and their entrepreneurial counterparts. For example, the marriage circles of entrepreneurs in both light and heavy industry, with the exception of artisan-types, were primarily restricted to the merchant and industrial bourgeoisie. Usually the wives shared the same bourgeois social background as their husbands. Consequently, the process of embourgeoisement was founded on a stable social base. The same also holds true for the marriage patterns of wage laborers from the same proto-industrial environment. For example, it can be presumed that a high percentage of the workers of the industrial region of the Erzgebirge at the turn of the nineteenth to the twentieth century were born into working-class families. Compared with the social formation of the bourgeoisie, it becomes evident that class affiliation and class origin were paralleled to a significant degree for both groups. Perhaps it must even be inferred that certain traits, such as rationality, work attitudes, and self-confidence, which are characteristic of both entrepreneurs (based on property, achievement, family tradition) and workers (based on the valuegenerating function of wage labor and on a claim in society earned through achievement), correspond to a specific dialectic of capitalism.

\section{The economic basis of class formation}

A second basis of class formation is the economic one. It should also be studied and presented in the context of a concrete relationship between the two groups of actors. At the same time, however, the participants should and must be measured against identical standards. The following is a rough outline of the method that should be applied. It is a feasible method, and I assume ${ }^{22}$ that its application would make a new sort of integrative social history possible in case studies, and later in more general, broader based research. The point is that entrepreneurs and wage laborers are both the producers and sellers of commodities in capitalism. This is one way to approach the constitution of class. In particular, it can be asked how both groups identified and pursued their interests within the given

"See Hartmut Zwahr, Zur Konstituierung des Proletariats als Klasse. Strukturuntersuchung uber das Leipziger Proletariat wallrend der industriellen Revolution (Berlin 1978, Munich 1981), pp. 115-203.

12 Hartmut Zwahr, "Konstitution der Bourgeoisie", pp. 149-186. 
framework of production and which means and methods they used in order to do this. Additional attention should also be given to the factors of parity and simultaneousness, or the lack thereof, and how congruence and incongruence of interests relate to these factors and to the pursuit of functionally comparable interests. Two areas are to be examined in each field of study concerning the economic basis of class formation: first, entrepreneurs and wage laborers as owners and producers; second, both groups as the sellers of commodities.

\section{Entrepreneurs and wage laborers as owners and producers}

The entrepreneur was the leading figure of production in the capital relation. As the owner of the means of production, commodities, and labor assets, as the buyer of labor power and the procurer of commodities, and as the hegemonic partner in a labor and power relationship, the entrepreneur was dependent on the wage laborers, who not only produced the commodities but who were the producers of their own labor power as well. The constitution of a bourgeoisie is based on material and conceptual foundations. It can be said that the material foundations originated principally from the system of production. To a great degree, both the bourgeoisie and the working class derived their self-image as well as the basis of their diverging interests from the production of commodities: the bourgeois as founder, organizer, financer, innovator, who pursued profitoriented productivity; the worker as the immediate producer of society's means of existence, which were socialized through private profit-seeking. Workers who had reached a certain level of class consciousness derived from this fact their rights to have a share of the product, to control production, and finally to be hegemonic. "The interest of workers and employers do indeed coincide", stated the Saxon industrial writer Wieck, "yet their related demands are not uniform. In this sense they diverge abruptly."43

At the heart of the history of entrepreneurs and enterprises was the pursuit of profits through the maximum exploitation of capital, specifically property, and the creation of conditions aiding exploitation for the purpose of industrial growth. This concept, understood as forced industrialization, corresponded to a new understanding of industrialization and had emerged within Germany from the debate among the Rhenish economic bourgeoisie. ${ }^{44}$ Material and conceptual origins of the bourgeoisie developed in both ways. In contrast to this, the economic interests of the working class were directed toward the development of individual labor power and its

43 Quote taken from Siegfried Moltke and Wilhelm Stieda (cds.), Albert Christian Weinlig in Briefen von ihm and an ihn (Leipzig 1931), pp. 296f. (letter dated 30 April 1848).

4 See Rudolf Boch, Grenzenloses Wachstum? Das rheinische Wirtschaftsburgertum und seine Indusirialisierungsdebatte 1814-1857 (Gottingen 1991). 
best possible valorization as a commodity. These owner interests conflicted with those of the entrepreneur.

The entrepreneurs in the early stages of capitalism viewed workers primarily as the owners of labor power. Workers had to be able-bodied and profitable. From this arose certain requirements concerning qualification and training and a limited provision of education. Workers needed to be in a position to feed themselves and others. The entrepreneurs presented themselves as providers and benefactors. The workers were dependent on the market, and as such they resembled the entrepreneurs. They were subject to entrepreneurial calculation and received a price in line with real market conditions. They were persons who could endanger order and property should basic needs not be satisfied. From this came the recognition that it was necessary to secure a minimum income, in those cases where this was not conceded for other reasons, and a bourgeois need for security, discipline and socialization. The entrepreneur assumed the role of teacher and public educator.

Wage laborers were seen as the objects of capital valorization, and .entrepreneurial motivation for helping them ranged from a sense of Christian responsibility and philanthropy to the calculated maintenance of minimal requirements of existence. The hard-working were promised advancement and entrepreneurial embourgeoisement. Yet, it was not the mindset of the entrepreneurial bourgeoisie that first elevated the worker to a subject of history that achieves a societal position according to its position as a productive force. It was fine for workers to valorize their property in wage labor, but not to become "citizens" of equal standing, perhaps through embourgeoisement. For a long time, embourgeoisement was closely guarded through the goals specified by bourgeois hegemony.

As a rule, the perspectives of the "labor question" changed as the working class evolved from its "raw state" and began to demonstrate its autonomy. Stated with some exaggeration, it was not until the working class developed anti-bourgeois behavior that it became worthy of integration into bourgeois/civic society. This process of integration was restricted not only by the bourgeois image of society, but also by way of the market dependency and the position of a class that supported itself with wages earned chiefly from manual and machine labor. As the owner of labor power, it was not in a position to protect and utilize this property in a manner typical of the entrepreneurial bourgeoisie. How many hurdles had been placed before it ever since it attempted to enter the labor market as an organized force! And yet in principle, it had, in its role as an owner, done nothing differently from its entrepreneurial counterpart.

Entrepreneurial and worker interests could join forces in a movement of occupational training in artisan associations, in Sunday schools, trade schools for improvement, and workers' education associations. The view that knowledge, perceived as civic education, meant power, undeniably 
has enlightened origins. One Chemnitz '48er thought that the "fully developed industry" represented a power that forced the worker "to think" and thus made him "independent in thought and action". ${ }^{45}$ The positive attitude toward steady work, the typical tendency to conduct one's life rationally and methodically, and the autonomous perception of interests had already began to flourish in the proto-industrial beginnings in which miners, weavers, knitters, lace-makers, etc. were included. Compared to this, the attitude of people in feudal labor relations tended to be more destructive and disobedient.

Such a comparison can only be outlined here. It is not possible to go into any further detail, and yet the entire scope of possible variations should also be considered in the following section.

\section{Property valorization through the sale of commodities}

The entrepreneur seeks the market for the purpose of profit, the wage laborer for the purpose of securing his or her existence by selling labor power for wages. If one compares them both as sellers of commodities, then in the case of the former, the individual is separate from the commodity, whereas in the case of the latter, the individual and the commodity are inseparably linked. Therefore, the worker is in a disadvantageous position while negotiating the work contract as compared to the seller of any other commodity. The person who buys the use of labor power takes possession of the individual selling it. In this context, he or she determines temporarily the use of people for capital valorization and at the same time attains authority over the wage laborer's person. For example: In the early industrial spinning factory, the labor power was kept in a servant status (primary patriarchalism). City ordinances protected this form of personal power not only against entrepreneurs who wished to entice workers from there, but also against wage laborers who wished to escape. Consequently, the workers were still in a fairly strong position in the textile mills of the early phase of industrialization, otherwise the entrepreneur would not have constrained them in this way.

In the second half of the nineteenth century, the relationship began to change. In the end, many working men and women had become disposable and exchangeable. Firing became a strong means of coercion. Out of the servant-like constraints on wage laborers arose a core of workers who were fairly safe from unemployment. The purpose of this rather crude outline is to demonstrate a methodological problem. This consists of examining and depicting property valorization on both sides of the capital relation through an analysis of the means and methods used by the entrepren-

4s Quole cited in Ernst Hofmann, "Die Entwicklung der Arbeiterbewegung in Chemnitz zwischen 1862 und 1866". Beiträge zur Heimatgeschichte von Karl-Marx-Stadt 25 (1982), p. 16. 
eur and the wage laborer in selling their specific commodities. For example: in the textile industry of the kingdom of Saxony, but not only here, an interest group for the trade emerged that was based on the tradition of linking the interests of entrepreneurs and wage laborers. Until 1848 it operated on the level of the "fatherland" (that is, Saxony), and afterwards on the "German" level (that is, national). The new form of interest consolidation illustrates protectionists in action. As the advocates of a strategy of national embourgeoisement, they directed the basic needs of the workers towards the path of state help. The alliance of spinning factory owners brought about the first statewide wage agreements. It also consolidated the practice of managerial authority. Along the lines of civic education, this was experienced by the workforce as "despotism" and "white slavery". The "subjugation of the free spirit" appeared to be incompatible with human dignity. ${ }^{46}$ The victims measured the industrial bourgeoisie against the civic ideals of liberty, equality and fraternity.

In this example of an alliance within a branch of industry, the textile entrepreneurs first departed from the principle of a free market economy, -without granting the men and women of the working class the same opportunity. The demand for maximum customs protection and higher prices in the domestic market reflected the entrepreneurs' interests; it could also have led to an improvement in the price of working-class labor power. Because the entrepreneurs had linked worker interests to state help, the workers instead lagged behind economically as sellers of commodities. They still did not have an equally effective strategy of commodity valorization in a developing market-oriented society. With this in mind, strikes and trade unionization should be seen as developments that corresponded in good measure to the branch alliance of the entrepreneurs or comparable interest associations. In that way, simultaneities and dislocations of social and economic action can be related to processes of class formation, interaction and changes in the contextual framework. It was solely for this purpose that the very fragmentary examples presented here were even included. They relate not only to the factors that encouraged class formation, but also to those that led to class de-formation (to borrow Jürgen Kocka's term) on the economic, social, and political level. ${ }^{47}$

\section{The political basis of class formation}

The emerging bourgeois/civic society was the result of defeudalization and embourgeoisement. Modes of thought of the new middle class were incorporated to some degree in all classes and social groups. Even the working class can be considered to be a product of civic society since it

\footnotetext{
46 "Arbeiterzustunde", Dresdner Tageblatt, 31 January 1847.

"Tee Jurgen Kocka, Lohnarbeit und Klassenbildung. Arbeiter und Arbeiterbewegung in Deutschland 1800-1875 (Bonn 1983), p. 30.
} 
absorbed very many of its elements. If it had not done this, the working class would not have been able to function in a system based on capital valorization through profit maximization. Yet in the view of the majority of at least the original entrepreneurial bourgeoisie and Bildungsbürgertum, the sphere of production was the only one in which the working class was permitted to resemble the bourgeoisie. A comparison of bourgeois elites across Europe reveals how great the consensus on this was. The fact that workers refused in the first half of the century to be content with the place in society assigned them by the nobility and the bourgeoisie is linked in a very elementary manner with their own application of civil values. This adaptation of civil values enabled them to view themselves and the position of their own class from the perspective of the ideals of liberty, equality and fraternity. At the same time, class position, exclusion and delimitation made possible the formation of the working class into an independent historical subject (with smooth transitions to the politics of other classes and strata). This did require that the working class assimilate civil values not only in the national context but also in the international context of the bourgeois epoch.

Class interests led workers not only to assimilate a modified form of bourgeois achievements but also to include them into their own basic value system. In this way they achieved their own set of goals and political education. They began to apply these practically. During this entire period, forms of self-help can be traced, such as trade unions and cooperatives, while a minority, whose political influence was growing, sought political solutions of a more fundamental nature and supported the creation of a socialist party. The bourgeois vision of the liberated individual, who is assimilated into a society of liberty, equality and fraternity, was projected onto the classless, socialist society of the future. It was linked with the vision of a "new" man. Without this prerequisite stage of embourgeoisement and the subsequent anti-bourgeoise effects, the labor movement would have not been able either to find acceptance of such an anticipated future or to lay the groundwork for its realization. A new element was the perspective of internationalism, then hardly evident among the bourgeoisie. In capitalist society, socialization and solidarity occurred on a national premise, later to become a nationalistic one on the eve of the First World War.

The formation and modernization of bourgeois society in the countries of central and western Europe prior to the First World War are not conceivable without the pressure for societal change exerted by the labor question first in England and then on the Continent beginning in 1830 and especially from mid-century onward. However, within capitalism the pressure posed by the masses of wage laborers was not dysfunctional; in fact, in many ways it helped to optimize the system. This happened in the factories as well as at the community and state levels. To a great degree, cooperative self-help developed at the same time. The steady growth of 
real income and the increase in political participation were both trends that not even the formidable First World War could permanently disrupt. "The labor movement and prewar bourgeois society. An attempt to take stock of a century" should be the topic that would follow the considerations presented here.

Translated by Donah Geyer and Marcel van der Linden 